\title{
Essays on natural codes: probably and improbably (I)
}

\author{
Miloje M. Rakočević \\ University of Niš, Faculty of Sciences and Mathematics, Department of Chemistry, \\ Višegradska 33, 18000 Niš, Serbia

\begin{abstract}
В сисстемах небесных сфер ... верояатно, совершались $и$ совершаться продолжают изменениия, подобные тем, какие перед нами протекают при химических реакииях частии ... Грядущиий Ньютон найдет законьл подобных изменений. В химии они хотя и своебразны, но, конечно, представляют только вариации на общую тему гармонии, изарствующей в природе.
\end{abstract}

Д.И. Менделеев (Периодический закон, 1958, с. 554)

\begin{abstract}
The text represents a narration of narration. First, an article was written on the analogies of the genetic and chemical code (MMR, 2018b), and then its Supplement 1 (MMR, $2020 \mathrm{~b}$ ); both articles written in standard scientific language, without associations and contexts that would lead to other topics and other scientific disciplines. However, it proved necessary to do both in this third step, which required an essayistic way of telling. Only such a way made it possible (with the hope that I succeeded in that) to say directly where "iacet lepus": the existing paradigms in current chemical and biological science are the reason for "preventing" insight into analogies and a kind of unity of natural codes.
\end{abstract}

Introductory note. Why essays, and why the first one titled "Probably and improbably"? I assume that the readers of my works on natural codes (genetic and chemical, above all, but also on the code of natural language; all together - on the universal code of nature) know that these works deviate from the paradigm valid in the so-called "current science". But none of them - my readers - mentioned the paradigm in any comments, nor did I, for the simple reason that I would not question the publication of the article. Now it can no longer be postponed, if the full truth is to be expressed (at least as I see it). And in order for that to be possible, a different genre of narrative is necessary, precisely the essay, ${ }^{1}$ which I am approaching.

\footnotetext{
1 "The essay leads nowhere but, on the contrary, brings any bolder ..., astonishing hypothesis and conception that comes to mind - into the reality from which they (those hypotheses and conceptions) arose" (Mikhail Epstein = Mihail Epštejn, 1997, p. 17).) [In encyclopedias today, the name of M. Epstein is placed on the same level with Noam Chomsky and Umberto Ecco.] Despite the freedom and comfort in setting hypotheses and concepts, the essay, paradoxically, requires more precise language in narration than standard scientific. Hence my decision to write these essays bilingually; the original written in my native tongue (Serbian) to be translated into English, so that the reader is not in doubt about what I wanted to say, if sometimes my English fails. This is true for the basic text of the essay, but not for the legends of the
} 
To better understand what I am talking about, I will give an example. After forty years of research, ${ }^{2}$ two of my works, published in Elsevier's journals two years ago (MMR, 2018a,b), represent in some way the epilogue of all my research: they contain a new paradigm! In the first case, by pointing out that in order to understand genetic code (GC), in addition to the term code, the terms the cipher of the code and cipher key are also necessary; and in the second case, the attitude from which it follows - in order to understand the Periodic system of chemical elements (PSE), it is necessary to understand that PSE is actually a chemical code. In Supplement 1 for the article (MMR, 2018b), I went a step further than the original: the newly discovered regularities in isotopy are more than a trend: "It is not just a trend only, but an unexpected agreement of experimental results with an unexpected model." Unexpected agreement, with unexpected model. That statement also contains the meaning of the title of this essay: unexpected as improbable and vice versa.

The power of paradigm. In Box 1, we have a testimony to the essence of the paradigm of current chemical science: from 1970 and 2015. Both times it is said that it is a convention when the question is asked what is the essence of chemical science in general, and, in particular, the essence of PSE. In doing so, Prof. Grdenić points out that during the hundred years of validity of the phlogiston paradigm, although incorrect theory, chemical science has nevertheless advanced in its development. In a way, as I see it, a similar situation has recurred in our time, over the last hundred and ten years, from 1911 to the present day. Namely, after the discovery that the atom is not a simple and indivisible but a particle of complex structure (Rutherford, 1911), interest in those works of Mendeleev in which the possible correspondence of the order of chemical elements in PS with the series of natural numbers and specific laws of that series ceased. With the discovery of the structure of the atom, Mendeleev's Periodic System practically disappeared from chemistry, and was replaced by the Periodic Table, permanently further modified and in its versions it grew to over a hundred variants. Therefore, the chemistry of the test tube is on the scene all the time, instead of the system chemistry (MMR, 2019b, 2020a).

illustrations that I originally write in English, because there, due to the taxative narration in the legends, ambiguities are generally no expected. [Serbian, as an inclusion on www.rakocevcode.rs ]

2 At the end of 1980, my master's work in the field of chemistry teaching was completed and bound in the form of a master's thesis. ... My professors-mentors thought that, going in the same direction in research, I could do a doctorate in a relatively short time, also in chemistry teaching. However, in the meantime a new idea flashed to me, I felt that I finally had a fundamental topic in my hands, and I suggested to my mentors that I do a doctorate in biochemistry ("Information approach to researching the biochemical basis of genetic processes"). And so, for 40 years now, I have not stopped researching the genetic code, so that, in the meantime, I would expand the field of research to the universal code of nature. 
Box 1. Contents from which the paradigm in current chemical science can be seen

"According to Th. S. Kuhn, the scientific revolution changes the paradigm, concept or pattern, according to which scientists conduct researches and interpret their discoveries (Kuhn, 1970) ... Phlogiston theory was a chemical paradigm to which chemists adapted all their observations and discoveries, as long as Lavoisier did not reject it in $1789 .{ }^{3}$ It was a scientific revolution in chemistry that introduced real chemical elements. The definition of a chemical element did not need to be changed. After Lavoisier chemists were confronted with atomistic. To Lavoisier, atoms were a matter of philosophy, not chemistry, because he saw no way to prove them by experiment. ... In the summer of 1970 in Snowmass-at-Aspen, Colorado, the Chemistry Teaching Section of the American Chemical Society, in collaboration with the International Union of Pure and Applied Chemistry (IUPAC), organized a Conference on Chemistry Teaching. Among other issues discussed was what chemistry was in 1970 and what it would be like in the near future. An extensive report on the Conference was published in the January 1971 issue of the Journal of Chemical Education. Conference participants, including prominent American physical chemist G. Hammond (b. 1921) and British inorganic chemist Sir Ronald Nyholm (1917-1971), agreed that teaching chemistry depends on the teacher's understanding of chemistry and its task. That's why it's best to say "that chemistry is what people who call themselves chemists do". In the end, however, they accepted the definition: "Chemistry is a comprehensive study of the preparation, properties, structure and reactions of chemical elements and their compounds, as well as the systems they make up." They found that from 1850 until today there have been no significant changes in answering the question of what chemistry is" (Drago Grdenić, History of Chemistry, Zagreb, 2001, Novi Liber and Školska knjiga, in Croatian).

"The task group does not intend to recommend the use of a 32-column periodic table or an 18column. This choice which is a matter of convention, rather than a scientific one, should be left to individual authors and educators. The task group will only concern itself with the constitution of group 3. Once this is established, one is free to represent the periodic table in an 18 or 32 column format." ("Project Details The constitution of group 3 of the periodic table" (IUPAC document): "Project No.: 2015-039-2-200; Start Date: 18 December 2015; Division Name: Inorganic Chemistry Division; Division No.: 200") [This citation I have given in (MMR, 2018b, in Appendix).]

${ }^{3}$ At this place Prof. Grdenic explains how the phlogiston theory was founded: "In 1669, Johann Joachim Becher (1635-1682) proposed three 'earths' for chemical elements - fatty, glassy and mercury earth, and Georg Ernst Stahl (1659 - 1734), in 1723 fatty earth called phlogiston and used it to explain burning and other chemical changes." Therefore, the calculation shows that the "chemical element", called first fatty earth, and then phlogiston, was on the scientific scene for 120 years. 
Box 2. The excerpt from: MMR, 1994a, p. 176

Mendelian concept includes both geometrism and the unit change law; in other words, it is a concept that immediately must correspond to the genetic code (Prediction 11.1). But, we'll quote Mendel himself: „Bezeichnet $n$ die Anzahl der characteristischen Unterschiede an den beiden Stammpflanzen, so gibt $3^{\text {n }}$ die Gliederzahl der Kombinationsreihe, $4^{\mathrm{n}}$ die Anzahl der Individuen, welche in der Reihe gehören, und $2^{\mathrm{n}}$ die Zahl der Verbindungen, welche konstant bleiben. So enthält z.B. die Reihe, wenn die Stammarten in 4 Merkmalen verschieden sind, $3^{4}=$ 81 Glieder, $4^{4}=256$ Individuen und $2^{4}=16$ konstante Formen; oder was dasselbe ist, unter je 256 Nachkommen der Hybriden gibt es 81 verschiedene Verbindungen, von denen 16 konstant sind" (Mendel, 1866, p 22; underlined by M.R.). According to Mendel, in given example, the 16 "Verbindungen" that represent the 'phenotype' at the same time belong to the "Verbindungen" of the 'genotype' which number is 81 totally. But, it is more important that, according to Johannsen, a system of the hybrid cross is determined only by the two entities ('phenotype' and 'genotype') while, according to Mendel such system is determined by the four entities: $1^{\mathrm{n}}-2^{\mathrm{n}}-3^{\mathrm{n}}-4^{\mathrm{n}}$ $(n=1,2,3 \ldots):$ Stammarten - Konstante Formen - Glieder - Individuen; viz, in modern language: Parent-type - Phenotype - Genotype - Individual-type. The Johannsen`s model does not correspond to the genetic code in any way from the aspect of code characteristics as already explained in this study. The Mendelian model, however, represents in fact the union of Trinity-Quaternity in a sense that only the first entity (Stammarten) is allowed to be separated from the Quaternity system (note that Mendel only uses the term Stammarten, i.e. Stammpflanzen for the first entity but not the mathematical expression $1^{\mathrm{n}}$ which we use for the explanation of the Mendelian idea). The Mendelian model also represents the performance of the unit change law on the two levels as it is immediately selfevident. Finally, it is possible to demonstrate that the codons in the system of 64 codons in the genetic code can be classified according to the Mendelian model of "four entities" (that makes a sense of Prediction 11.1) (see Addendum 3).

Sister paradigms. ${ }^{4}$ To make matters worse, it happened, by some strange coincidences, that parallel in biology, possible connections with the possible order of things in Nature (corresponding to the series of natural numbers) were erased and paradigms of chance and randomness were established on the scientific scene. Mendel's work on the basis of

\footnotetext{
${ }^{4}$ By introducing a handful of inter-titles, parallel with a handful of boxes, this essay, with its structure, enters a specific area of the essay genre, the leaf-genre. ("The classic of this genre is Vasili Rozanov's Fallen Leaves. But, the second picture is closer to me: sticky spring leaves ... like the beginnings of thoughts that have not yet unfolded into any big 'forest grove', open to the future. ... The leaf is genre, in the middle between [note] and essay: it is a developed [note] or short essay. Of course, there are various leaves: small are birch, large - maple, medium - oak, linden, elm ... invite the reader, different shapes and sizes of slips will appear in front of him.") (M. Epstein = M. Epštejn, Sticky slips = Lepljivi listići, 2015, p. 5, in Serbian).
} 
modern genetics (Mendel, 1866) was rediscovered, and the experiments with garden peas described in it were performed again in 1900. Despite Mendel's description of genetic output so clearly and unambiguously corresponding to a series of natural numbers (1-2-34) (Box 2), Johansen reduced it all to two terms: genotype and phenotype. Instead of researchers having fun with Mendel's "miracle" four, it was easier to obscure everything with simple arbitrariness. ${ }^{5}$ it was just missing to say, as in chemistry, "that genetics is what people who call themselves geneticists do." [In a way, the introduction of the term genotype-phenotype is analogous to the introduction of the term "atomic number" in chemistry, as a substitute for the "ordinal number" of an element, as was originally the case with Mendeleev. It is even more incredible that a convention has been established according to which one does not take the natural unit of mass - the mass of one hydrogen atom, but the twelfth of the C-12 isotope ?!]

As far as Darwinism is concerned, everything is left to that, as if Darwin saw (and viewed) only mere coincidences, and did not see the order of moves (selection steps) that maintain the unity of the "codon ring" and the "mutation ring", as R. Swanson presented a few decades later (Swanson, 1984). And, in fact, he saw that, despite coincidences, biological taxonomic outcomes strictly correspond to the series of natural numbers, and he sophisticatedly expressed all this in one and only illustration (diagram) within his unique book The Origin of Species, about which I wrote in details in several times (MMR, 2017c).

In the search for a common and unique logic of natural codes, it was logical to expect (it was probable) that De Saussure's contribution to understanding the common characteristics of all natural codes, expressed in the structure of hierarchical systems be viewed: from the simplest to the most complex element; from the constituent at least to the greatest complexity, all the way to natural spoken language with voices from the least to the greatest openness (Box 3).

Box 3. The excerpt from: Ferdinand De Saussure, Cours de linguistique generale

"On classe généralement les sons d'après le lieu de leur articulation. Notre point de départ sera différent. Quelle que soit la place de l'articulation, elle présente toujours une certaine aperture, c'est-à-dire un certaine degré d'ouverture entre deux limites extrêmes qui sont: l'occlusion complète et l'ouverture maximale. Sur cette base, et en allant de l'aperture minimale à l'aperture maximale, les sons seront classés en sept catégories désignées par les chiffres $0,1,2,3,4,5,6$. C'est seulement à l'intérieure chacune d'elle que nous répartirons les phonèmes en divers types d'après le lieu de leur articulation propre" (De Saussure, 1985, p. 76).

${ }^{5}$ It was only with the deciphering of the human genome, and the insight into the greater importance of epigenetics, that it was realized that Johansen's genotype-phenotype model was at least insufficient. 
Self-censorship. B.M. Kedrov, a chemist and philosopher, the scientist who most thoroughly researched the Mendeleev Archive, testified in his book (1977) that he did not come across any document or paper from which it would be seen what methodology Mendeleev used in his researches. In the said book, Kedrov also enclosed 16 photocopies from the Archive (between pages 128 and 129, a kind of Small Archive), of which 14 refer to PSE. After a long insight into those photocopies, I concluded that in almost all photocopies Mendeleev also deals with the issue of the relationship of PSE with the series of natural numbers and the specific laws of that series. In my opinion, those are the facts, and Mendeleev neither spoke nor wrote about those facts. He was silent, which was a kind of self-censorship. [Mendeleyev's photocopies can be found on my website (www.rakocevcode.rs) (Mendeleyev's Archive), as well as in the Proceedings "Harmony of Genetic Code, Vol 2" in OSF Preprints (DOI 10.31219/osf.io/89uah). In the mentioned Proceedings are also my works on universal consciousness in relation to the universal code of nature.]

Darwin was also silent (MMR, 2017c). In their time (the time of Darwin, Mendel and Mendeleev), if any researcher referred to the possible correspondence of anything with natural numbers, he would be immediately accused of Pythagorean numerology (today it is even worse in that respect). [Andrea, I. Woody, a chemist and philosopher from the University of Washington, also testifies to this in his highly studious work on Mendeleev (MMR, 2020b, footnotes 8 and 10).]

De Saussure was also mostly silent, but, as we have seen (Box 3), he distanced himself from current linguistics with at least one statement ("Our starting point will be different"), pointing out that the whole system of phonemes should be considered first, and only then in parts of the system explore the hierarchy in the articulation of voices.

In the silence of the Moravian Monastery, of which he was abbot, Gregor Mendel performed his genetic experiments on the garden peas (mostly silent about current science) and drew his own unexpected, that is "improbable" conclusions (Mendel, 1866). So unexpected that when current science, 44 years later, discovered his work, and with all praise repeated his experiments, it left out, at least for the next 110 years, his most important result, the result concerning the universality of natural codes - the quartet sequence $1-2-3-4$ in the form $1^{2}-2^{2}-3^{2}-4^{2}\left(1^{\wedge} 2-2^{\wedge} 2-3^{\wedge} 2-4^{\wedge} 2\right)$ (Box 2).

Quartet sequences. How much consciously, and how much unconsciously, is now less important, but the fact is that the analogous quartet sequence was discovered almost 120 years later by R. Swanson in the genetic code (Swanson, 1984). To make the matter be more improbable to the end, I gave myself the freedom to associate her quartet sequence with De Saussure's, a formally identical quartet sequence of the language code, in the form of a logical square: 0-1-2-3 (MMR, Fig. C2, p. 42). For the sake of not only truth, ${ }^{6}$

\footnotetext{
6 "Reasoning should retain its rights everywhere and always: and the right is to see in that subject and elsewhere, what the truth shows to it (to the Reasoning)" (Michel de Montaigne = Mišel de Montenj, 2001,
} 
but also beauty, ${ }^{7}$ I made Darwin's silent and hidden, as well as "double", quaternary sequence: [9 (10 - 26) 27] / [9 (8 - 17) 27], in which "duality" there is also a connection between the genetic and chemical code (MMR, Tab. C2, third quadrant, p. 39).

Scenario by atlas. The first Supplement to the article on the analogies of the genetic and chemical code (MMR, 2020b as S1) brought new quartet sequences, contained in both codes, in such an unexpected ("improbable") way, that it almost escapes the possible usual interpretation of their relations. Finding no other option, I opted for the Atlas of Illustrations, among which the scenario of generating sequences finds its place, both in Supplement 1 and in this essay. ${ }^{8}$

A predictive hypothesis. The final act in Supplement 1 was performed via Table S1-14. Two and two quartet sequences (one smaller and one larger) are given separately: in the upper part for the genetic code (GC) and in the lower part for the chemical code (CC): (2-4-6-8 / 48-50-52-54) versus (16-18-20-22 / 62-64-66-68). The difference between the members of the larger and smaller sequence is the same in both cases and is 46 (48 - $2=$ 46; 62 - 16 =46). My hypothesis for further research is that it will be shown that this "46" has to do with "23" in the Standard GC Table. (The number 46 is twice the value of the number 23; only doubled can it enter into the relations of quartet sequences of even numbers.).

Preliminary proofs for the hypothesis are given in the Atlas. First, Survey 1 presents the uniqueness of the sequence 62-64-66-68, in that its distance from the beginning and end in the set of four even two-digit numbers is such that the ratio is $1: 2$, which corresponds to "symmetry in the simplest case" (Marcus, 1989). Then, in Surveys $2 \& 3$, the uniqueness of the sequence $0,1,2,3$ in the Periodic Table of Numbers is shown (starting from S1-Tab. A4); which sequence represents the beginning of both a series of natural and a series of Fibonacci numbers. ${ }^{9}$ The position of numbers in the system of Generalized Golden Section (Table 1 in relation to Figure 1) is also in support of the hypothesis.

p. 178; italics: MMR). Michel de Montaigne was the first to introduce the essay genre into literature. Later, a philosophical essay was written, and, finally, a scientific essay. The text I am writing here, and handing it over to the reader without hesitation, is my way of writing a scientific essay.

7 "Beauty is truth, truth is beauty - that is all Ye know on earth, and all ye need to know" (John Keats, 1795 - 1821): The last two verses of the poem Ode on a Grecian Urn, about which the most has been written in literary criticism and literary analysis.

${ }^{8}$ The illustrations in this essay are marked as usual: Figure 1 - Figure 2; Table 1 - Table 4; Survey 1 Survey 4; Scenario 1. The illustrations in Supplement 1 are referred to as follows: Table S1-1, Table S1-2, ..., Table S1-14; Table S1-A1, Table S1-A2, ..., Table S1-A10; Table S1-B1, Table S1-B2, .., Table S1B9; Survey S1-1, Survey S1-2, ..., Survey S1-14. All other references to previous works are given in the usual way.

${ }^{9}$ Tidjani Negadi dedicated an entire article to the uniqueness of number 23, from the aspect of arithmetic, algebra and other mathematical disciplines (Negadi, 2011). If the reader is wondering why I have the right to see the number 23 in the neighborhood of numbers 2 and 3, then I ask him to look at Table S1-1 where it 
Box 4. Several important quantities in Tables 2, 3 and 4

Table 2: The number 204 as the number of atoms in 20 amino acid molecules (in their "bodies", i.e. side chains), and the number 180 as the number of atoms in 20 AAs "heads"; in total, it is 384 , which quantity we find in Plato's geometric progresion, as well as in the specific ratio of codon octets on the 6-bit binary tree of GC (S1-Table B4 in relation to S1-Table B3). Quantity 530 as the sum of the first three perfect numbers $(6+28+496=530)$.

Table 3: The last quantity in Schcherbak's Table of Multiplications of Number 37 is $27 \times 37$ (Shcherbak, 1994, Table 1), and here we went one step further: 28 x 37 . Number 530 as the sum of the first three perfect numbers. The number 476 represents the sum of the numbers in the last octet on the 6-bit binary tree $(56+57+\ldots+63=476) ; 384$ as $284+100$ where 284 is the second friendly number; 628 as a pair member of numbers 627 and 628 which together give the total number of nucleons in 20 AAs (1255).

Tabela 4: The only novelty is the result $(2 \times 530)+204$, where 204 is the number of atoms in the side chains 20 AAs.

Final comment. With Survey 4 again ("on the small door") we enter Supplement 1, exactly at S1-Surv. 4, because of two things. First, to correct the error that crept in there; ${ }^{10}$ and, second, to test the relationships between the sequences from the aspect of system that we have previously proved for GC in at least two cases. The first time in (MMR, 2011b, Fig. 6, p. 832) and the second time in the Table given in (MMR, 2017d, Tab. 4, p. 13) which Table is attached in this essay as Figure 2. Starting therefore from Survey 4, the relationships of the quartet sequences GC and CC are given further in Tables 2, 3 and 4. The test results are the most important quantities (determinants) of both genetic and chemical code that are generated from the relationships of the given sequences and are contained in the Tables themselves (Box 4). With the presentation of these results, we end this first part of the essay, so that in the second part we can move on to the details, one fine day, I hope in the near future (and this is more a time of hope than security).

is shown how the Fibonacci sequence 2-3-5-8-13 "dresses" in a decade spirit and becomes 20-30-50-80130. Numbers 2 and 3 are one-digit numbers, but they can be further decadically combined, which is what we find in natural codes.

${ }^{10}$ The difference between 62 and 42 is not 60 but 20, as it is accurately written here now in Survey 4. 


\section{References}

Castro-Chavez, F. (2010) The rules of variation: amino acid exchange according to the rotating circular genetic code. J. Theor. Biol. 264, 711-721.

De Saussure, Ferdinand (1985) Cours de linguistique generale, Payot, Paris.

De Sosir, Ferdinand (1989) Opšta lingvistika, Nolit, Beograd.

Epštejn, Mihail (1997) Esej, Narodna knjiga /Alfa, Beograd.

Epštejn, Mihail (2015) Lepljivi listići, Dereta, Beograd.

Grdenić, Drago (2001) Povijest kemije, Zagreb, 2001, Novi Liber i Školska knjiga).

Hawking, S., Mlodinow, L. (2005) A briefer history of time, Bantam Books, US.

Johannsen, W. (1913) Elemente der exakten Erblichkeitslehre, Second Edition, Gustav Fischer, Jena.

Kedrov, B.M. (1977) Predictions of Mendeleev in Atomism - Unknown Elements, Atomizdat, Moscow.

Kuhn, Th.S. (1970) The Structure of Scientific Revolution, 2nd Edit., The Univeristy of Chicago Press, Chicago.

Marcus, S. (1989). Symmetry in the Simplest Case: the Real Line. Computers Math. Applic.17, 103-115

Mendel, G. (1866) Versuche über Pflanzenhybriden. Verhandl. Des Naturvorschenden Vereins in Brunn, IV.

Mendeleev, D. I. (1869) On the Relationship of the Properties of the Elements to their Atomic Weights, Zeitschrift für Chemie, 12, 405-406. [Reprinted in David M. Knight, ed., Classical Scientific Papers - Chemistry, Second Series, 1970.]

Менделеев, Д.И. (1958) Периодическая закон, Изд-во АН СССР, 1958, с. 1-839.

Montenj, Mišel de (2001) Zlatna knjiga života - Ogledi, Ušće, Beograd

Négadi, T. (2011) The multiplet structure of the genetic code, in one and small number, January 2011, NeuroQuantology, 9(4).

Platon (1888) Timaeus of Plato, editef with Introduction and Notes by R.D. Archer-Hind, M.A., fellow of Trinity College, Cambridge. London, New York: Macmillan and CO.

Platon (1970) Timaeus. Texte préparé et traduit par Albert Rivaud: Platon, Ouevers completes, tome X, Paris, 1970.

Popov, E.M. (1989) Strukturnaya organizaciya belkov, Nauka, Moskva.

Rutherford, E. (1911) The Scattering of $\alpha$ and $\beta$ Particles by Matter and the Structure of the Atom, Philosophical Magazine. Series 6, vol. 21. May 1911.

Rakočević, M. M. (1988) Geni, molekuli, jezik, Naučna knjiga, Beograd. (www.rakocevcode.rs)

Rakočević, M.M. (1991) The coherence of the chemical and genetic code, in: Proceedings of Faculty of Science (former: Faculty of Philosophy), Chemistry Section, 2, 1991, 1-29, Niš. 
Rakočević, M.M. (1994a) Logic of the Genetic Code, Naučna knjiga, Beograd. www.rakocevcode.rs)

Rakočević, M.M. (1994b) Does universal consciousness exist? (Emerging Logic of the Periodic System of Elements, Genetic Code and Human Consciousness), Toward A Scientific Basis for Consciousness, An Interdisciplinary Conference, The University of Arizona, Tucson, April 12 14, 1994. Program and Abstracts, p. 123, Poster Presentations, No 62.

Rakočević, M.M. (1995) The universal consciousness and the universal code, "Consciousness Scientific Challenge for the 21st Century", Symposium, May 29 - 30, 1995, ECPD, European Centre for Peace and Development of the United Nations University for Peace, Belgrade. http://www.ecpd.org.rs/pdf/2015/books/1995/1995_ecpd_consciousness.pdf

Rakočević, M.M. (1997a) Two classes of the amino acyl-tRNA synthetases in correspondence with the Codon path cube, Bull. Math. Biol. 59 (1997) 645-648.

Rakočević, M.M. (1997b) Genetic Code as a Unique System, Studentski kulturni centar Niš and Bina - Beograd, Serbia, 1997; http://www.rakocevcode.rs

Rakočević, M.M. (1998) The genetic code as a Golden mean determined system. Biosystems, 46, 283-291.

Rakočević, M.M. (2004a) A harmonic structure of the genetic code. J. Theor. Biol. 229, 221-234.

Rakočević, M. M. (2004b) Further generalization of Golden mean in relation to Euler's "divine" equation, FME Transactions (Faculty of Mechanical Engineering, Belgrade, Serbia), 32, 95-98, 2004; arXiv:math/0611095v1[math.GM]; http://www.rakocevcode.rs

Rakočević, M.M. (2008) Genetic Code: Four-Codon and Non-Four-Codon Degeneracy. arXiv:0802.1056v2 [q-bio.BM].

Rakočević, M.M. (2011a) Genetic Code: Four Diversity Types of Protein Amino Acids. arXiv:1107.1998v2 [q-bio.OT].

Rakočević, M.M. (2011b) Genetic code as a coherent system. NeuroQuantology, 9 (4), 821-841.

Rakočević, M.M. (2015a) Po(i)etics of universal poetic structures, in: Njegoševa po(i)etika, p. 128. Pitura, Beograd.

Rakočević, M.M. (2015b) Universal poetic structures - Njegosh's work in relation to the works of Homer and Dante, Serbian literary magazine, 2015 year, pp. 137-148. (Publisher: The Serbian Writers Assotiation, Francuska 7, Belgrade, Serbia.)

Rakočević, M.M. (2017a) Golden and Harmonic Mean in the Genetic code. OSF Preprint DOI 10.31219/osf.io/2pfe7

Rakočević, M.M. (2017b) Analogies of Genetic and Chemical Code (an expanded version), OSF Preprints DOI 10.31219/osf.io/mxecj

Rakočević, M.M., (2017c) Enigma of Darwin Diagram. OSF Preprint DOI 10.31219/osf.io/qzg69

Rakočević, M.M., (2017d) Genetic code: Chemical Distinctions of Protein Amino Acids, OSF Preprints DOI 10.31219/osf.io/86rjt

Rakočević, M.M. (2018a) The Cipher of the Genetic Code, BioSystems 171 (2018) 31-47. 
Rakočević, M. M. (2018b) Analogies of Genetic and Chemical Code, Polyhedron, 153, 292-298.

Rakočević, M. M. (2019a) Protein amino acids as a complete (periodic) system, Chemia Naissensis, Vol 2, Issue 1, pp. 1-43.

Rakočević, M. M., (2019b) Genetic code as an image of the mirror image. Part I, OSF Preprint DOI 10.31219/osf.io/xht4c

Rakočević, M. M. (2020a) Genetic code as an image of the mirror image. Part II, OSF Preprint DOI $10.31219 /$ osf.io/3svpz

Rakočević, M. M. (2020b) Analogies of genetic and chemical code. Supplement 1, OSF Preprints DOI $10.31219 /$ osf.io/34c8n

Rakočević, M.M., Jokić, A. (1996) Four stereochemical types of protein amino acids: synchronic determination with chemical characteristics, atom and nucleon number. J.Theor. Biol. 183, 345349.

Shcherbak, V. I. (1993) Twenty Canonical Amino Acids of the Genetic Code: the Arithmetical Regularities. Part I. J. Theor. Biol. 162, 399-401.

Shcherbak, V. I. (1994) Sixty-four Triplets and 20 Canonical Amino Acids of the Genetic Code: the Arithmetical Regularities. Part II. J. Theor. Biol. 166, 475-477.

Sukhodolets, V.V. (1985) A sense of the genetic code: reconstruction of the prebiological evolution stage, Genetika, XXI, 10, 1589-1599 (in Russian).

Swanson, R. (1984) A unifying concept for the amino acid code. Bull. Math. Biol. 46, 187-207.

Woody, Andrea, I. (2014) Chemistry's Periodic Law: Rethinking Representation and Explanation after the Turn to Practice, Routledge volume Science After the Practice Turn in Philosophy, History, and the Social Studies of Science, edited by L. Soler, S. Zwart, V.Israel---Jost, and M. Lynch.https://www.amazon.com/Science-Practice-Philosophy-History-Routledge/dp/0415722950 (Amazon Best Sellers Rank: \#10,193,928)

Academia.edu:

https://www.academia.edu/3849078/Chemistry s Periodic Law Rethinking Representation and Explanation_after_the_Turn_to_Practice

Zloković, M. (1955) Divina proportione is not equal to sectio aurea, Pregled arhitekture, Beograd, 4-5, 1955. 


\section{ATLAS OF ILLUSTRATIONS}

Scenario 1. Generating of quartet sequences

\begin{tabular}{|c|c|}
\hline Illustrat. & Sequences \\
\hline S1-Tab. 3 & $62-64-66-68$ \\
\hline S1-Tab. A2 & $48-50-52-54$ \\
\hline S1-Tab. 13 & $16-18-20-22$ \\
& $42-44-46-48$ \\
S1-Surv. 4 & $72-74-76-78$ \\
\hline
\end{tabular}

Survey 1. The uniqueness of Sequence 62-64-66-68

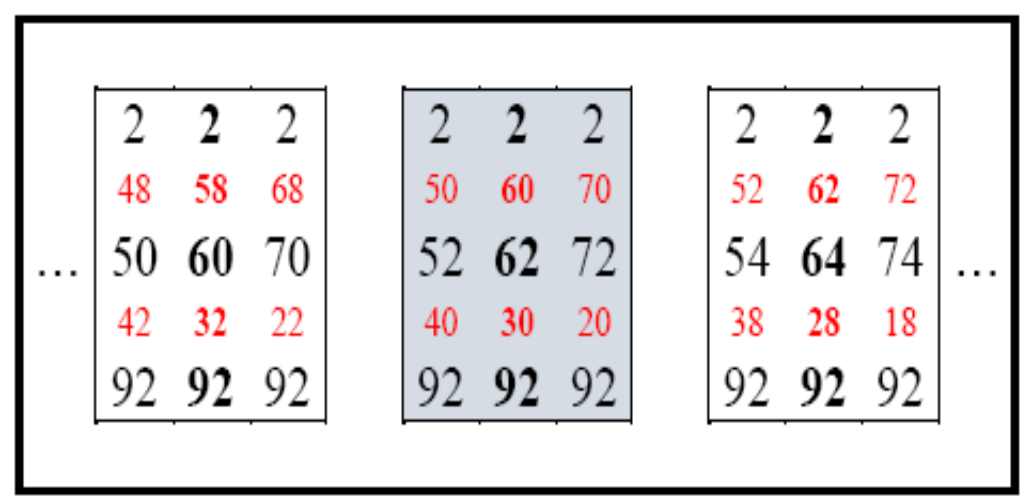


Survey 2. The uniqueness of relations among $2 \& 3$ and 23/32 (I)

$\left.\begin{array}{|cc|cc|ccc|}\hline 0 & \rightarrow & 1 \\ \downarrow 1 & & \downarrow 1 \\ 1 & 2 \\ \downarrow 1 & \downarrow 1 \\ 2 & \rightarrow & 3\end{array}\right]$

Survey 3. The uniqueness of relations among $2 \& 3$ and 23/32 (II)

\begin{tabular}{|c|ccccccccccc|}
\hline$(0)$ & -10 & -09 & -08 & -07 & -06 & -05 & -04 & -03 & -02 & -01 & 00 \\
$(1)$ & 01 & 02 & 03 & 04 & 05 & 06 & 07 & 08 & 09 & 10 & 11 \\
$(2)$ & 12 & 13 & 14 & 15 & 16 & 17 & 18 & 19 & 20 & 21 & 22 \\
$\ldots$ & & & & & & & & & & & \\
\hline \multicolumn{1}{l}{} & & & & & & & & & & & \\
\hline$(0)$ & 0 & $\mathbf{1}$ & 2 & 3 & 4 & 5 & 6 & 7 & 8 & 9 & \\
$(1)$ & 1 & $\mathbf{2}$ & 3 & 4 & 5 & 6 & 7 & 8 & 9 & 10 & \\
$(2)$ & 2 & 3 & 4 & 5 & 6 & 7 & 8 & 9 & 10 & 11 & \\
$\ldots$ & & & & & & & & & & & \\
\hline
\end{tabular}


Survey 4. Quantity relations in chemical and genetic code (I)

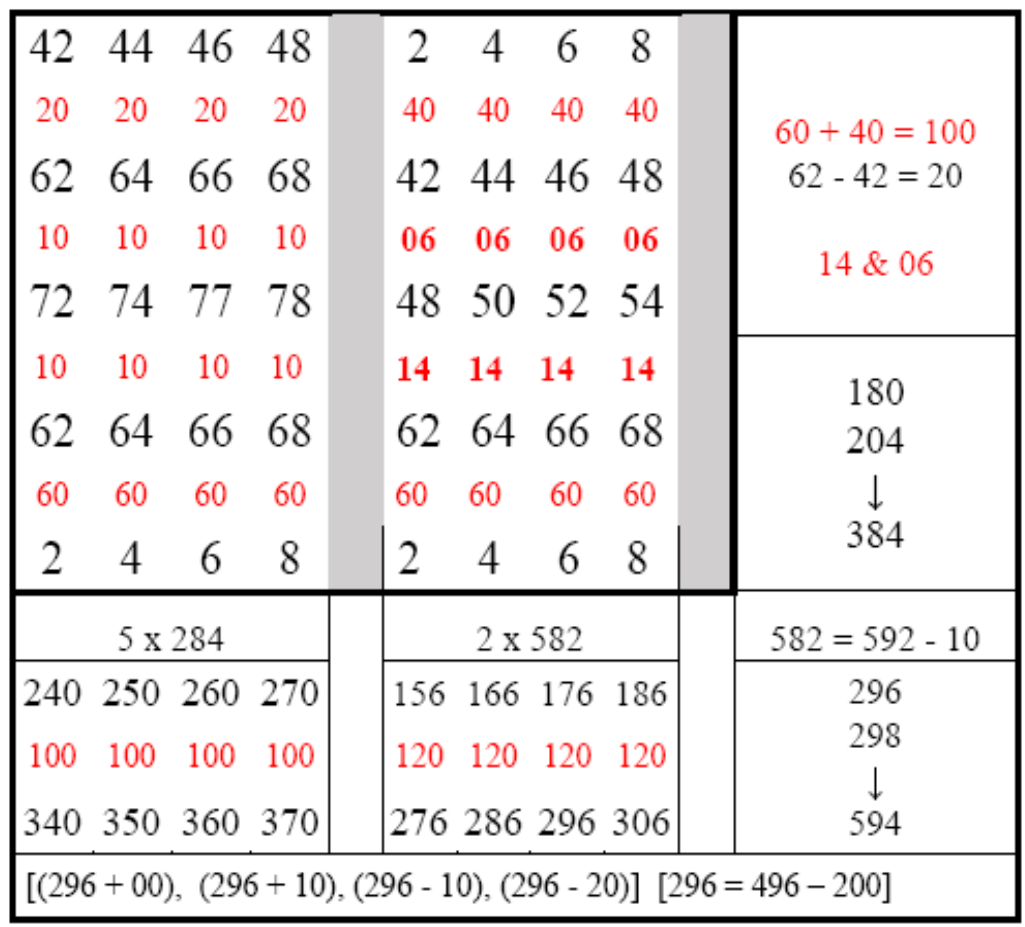


Table 1. The integer and non-integer solutions of Generalized Golden Mean (MMR, 2004b)

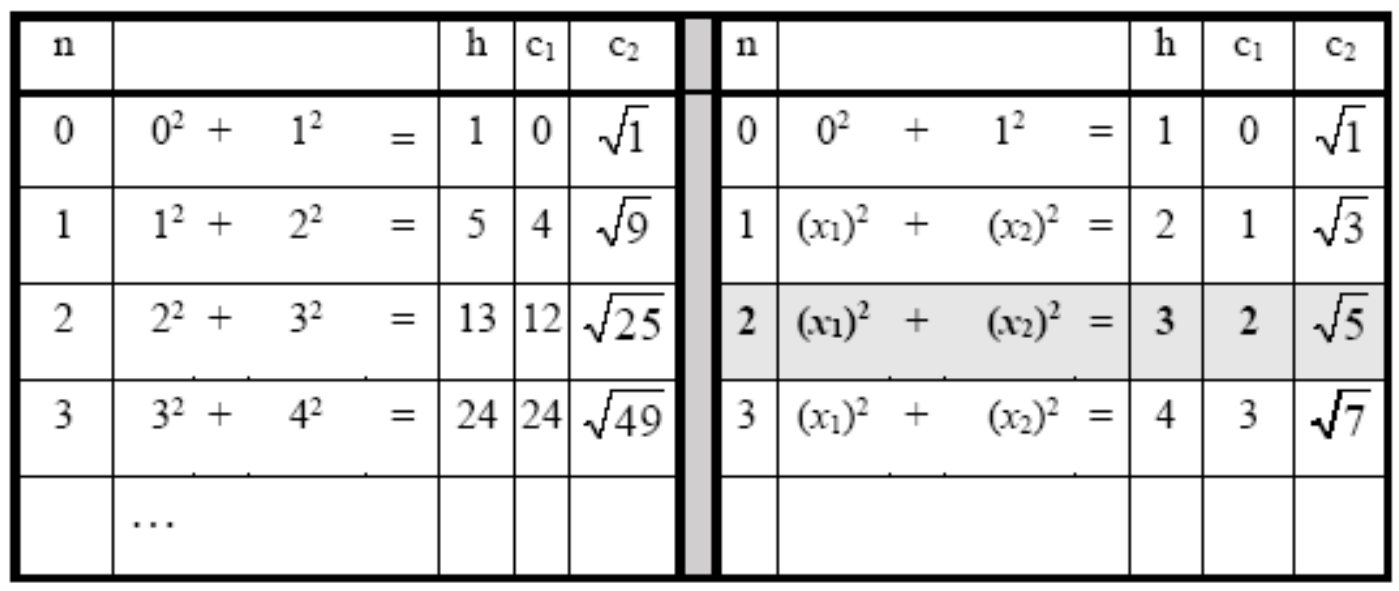


Table 2. Quantity relations in chemical and genetic code (II)

\begin{tabular}{|c|c|c|c|c|c|c|c|c|c|c|c|}
\hline 2 & 4 & 6 & 8 & 2 & 4 & 6 & 8 & \multirow{9}{*}{$\begin{array}{l}30 \\
14 \\
44\end{array}$} & \multirow[b]{4}{*}{30} & \multirow[b]{4}{*}{30} & \multirow[b]{4}{*}{30} \\
\hline 46 & 46 & 46 & 46 & 60 & 60 & 60 & 60 & & & & \\
\hline 48 & 50 & 52 & 54 & 62 & 64 & 66 & 68 & & & & \\
\hline 14 & 14 & 14 & 14 & 30 & 30 & 30 & 30 & & & & \\
\hline 62 & 64 & 66 & 68 & 92 & 94 & 96 & 98 & & 14 & 14 & 14 \\
\hline 46 & 46 & 46 & 46 & 44 & 44 & 44 & 44 & & 44 & 44 & 44 \\
\hline 16 & 18 & 20 & 22 & 48 & 50 & 52 & 54 & & & & \\
\hline 14 & 14 & 14 & 14 & 14 & 14 & 14 & 14 & & & & \\
\hline 2 & 4 & 6 & 8 & 2 & 4 & 6 & 8 & & & & \\
\hline & & & & & & & & & & & \\
\hline 130 & 140 & 150 & 160 & 206 & 216 & 226 & 236 & & & & $\begin{array}{c}100 \\
\downarrow\end{array}$ \\
\hline 120 & 120 & 120 & 120 & 148 & 148 & 148 & 148 & & $\downarrow$ & & 384 \\
\hline 250 & 260 & 270 & 280 & 354 & 364 & 374 & 384 & & & & \\
\hline & $2 x$ & 530 & & (384 & $-00)$, & 384- & 10), & , & $984-$ & & \\
\hline
\end{tabular}


Table 3. Quantity relations in chemical and genetic code (III)

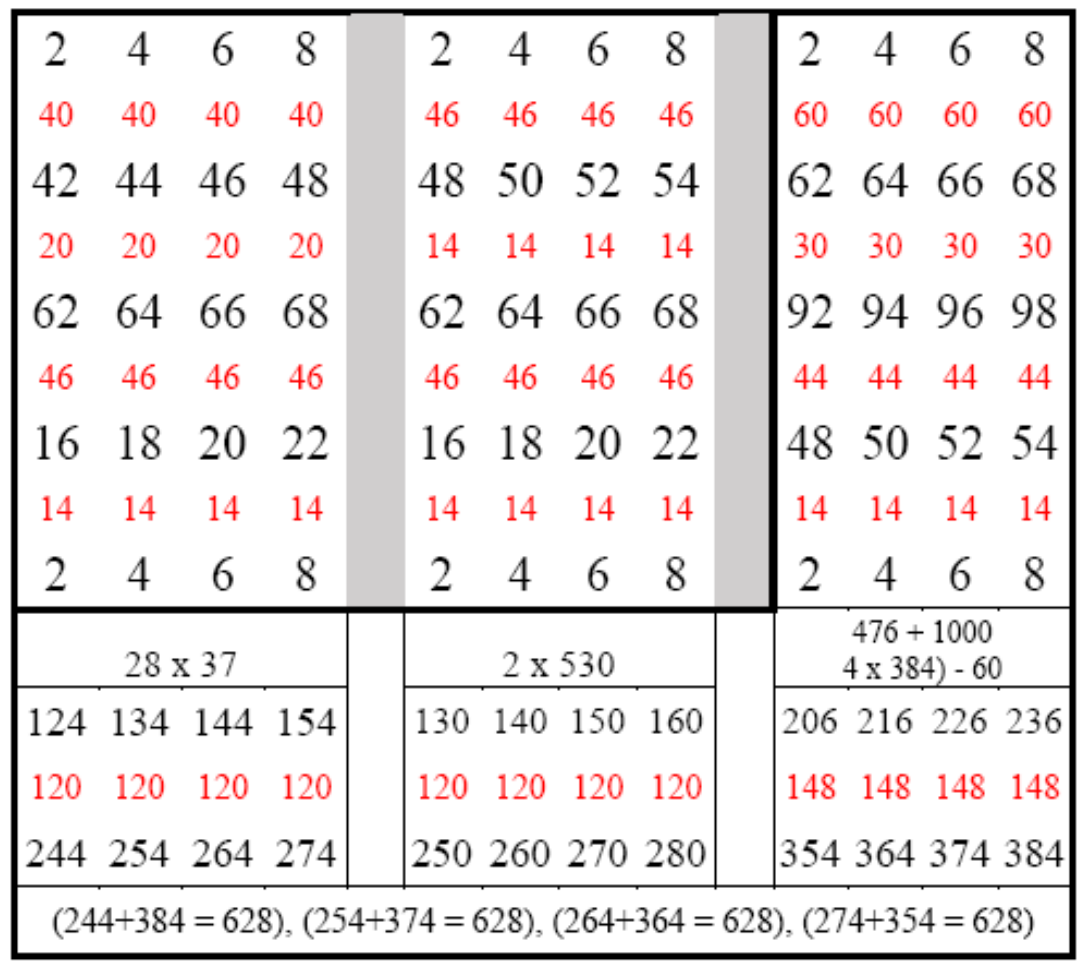


Table 4. Quantity relations in chemical and genetic code (IV)

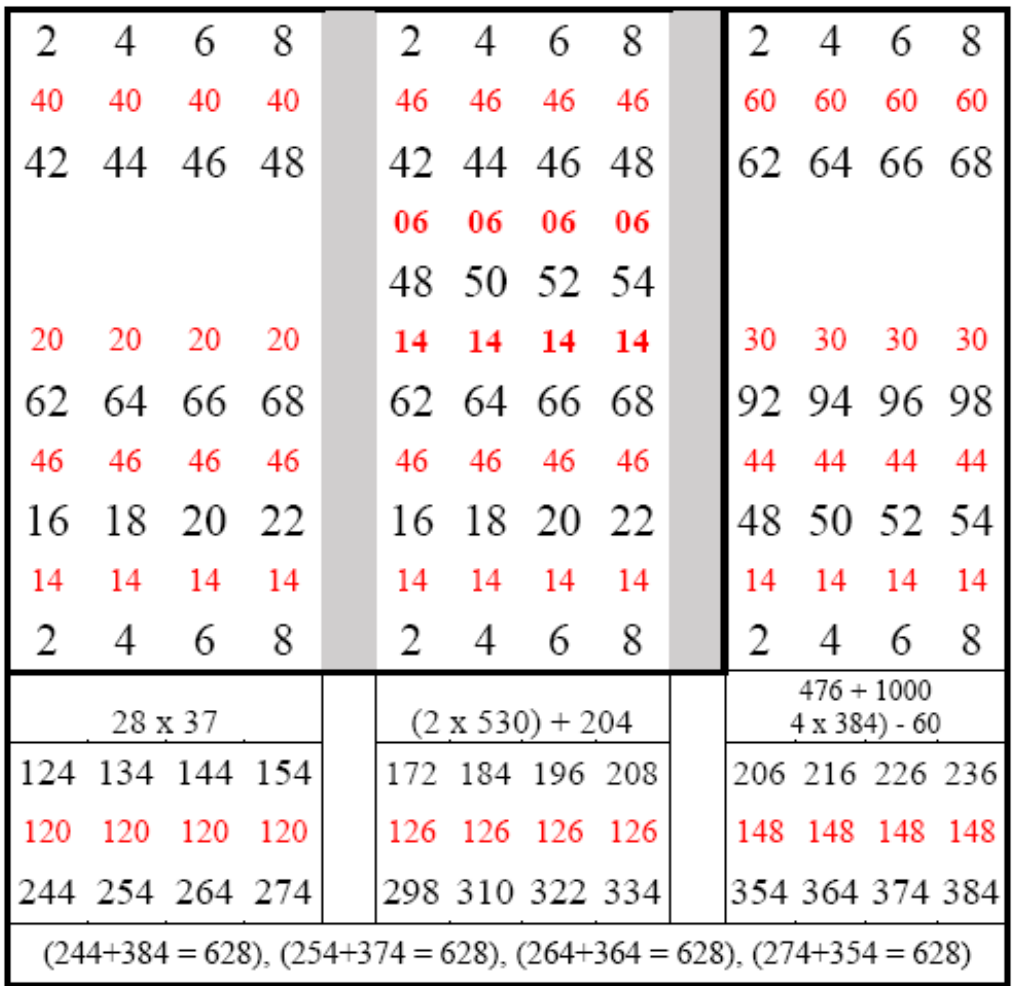




\section{Box 2. The first Luca Pacioli's triangle}
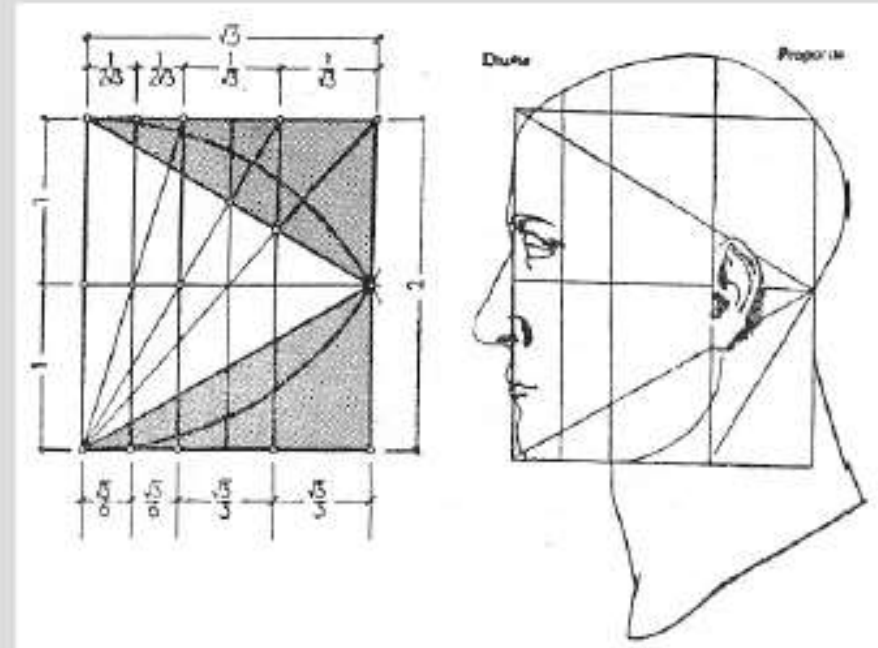

This Luca Pacioli's triangle appears as the first triangle in the right side of Table 1. The right side of Figure follows from original Pacioli's picture, while on the left side there is a Zlokovic's mathematical analysis (Zlokovic, 1955).

Figure 1. The first Luca Pacioli's triangle (MMR, 2004b, Box 2) 


\begin{tabular}{|c|c|c|c|c|c|}
\hline \multicolumn{4}{|c|}{119} & \multirow{3}{*}{$\begin{array}{l}\text { (33) } \\
(40)\end{array}$} & \multirow{4}{*}{120} \\
\hline G 01 & No8 & $\mathbf{L} 13$ & M 11 & & \\
\hline $\mathrm{A} 04$ & $\mathrm{D} 07$ & K 15 & F 14 & & \\
\hline V 10 & S 05 & R 17 & Y 15 & \multirow{2}{*}{$\begin{array}{l}\text { (47) } \\
(45)\end{array}$} & \\
\hline P 08 & Т 08 & Q 11 & $\mathrm{~W} 18$ & & \multirow{3}{*}{117} \\
\hline I 13 & C 05 & E 10 & H 11 & \multirow{2}{*}{$\begin{array}{l}\text { (39) } \\
\text { (33) }\end{array}$} & \\
\hline G 01 & No8 & L 13 & M 11 & & \\
\hline $24 / 13$ & $18 / 23$ & $40 / 39$ & $37 / 43$ & $118 / 119$ & \\
\hline (37) & (41) & (79) & $(80)$ & $117 / \mathbf{1 2 0}$ & \\
\hline & & 118 & & & \\
\hline
\end{tabular}

Figure 2. "A specific protein amino acids arrangement. The first row is repeated at the bottom, and thus one cyclic system is obtained. There are 117 atoms in two outer columns; at even positions 118, at odd 119; in two inner columns 120 atoms. On the other hand, in the lower half of the Table there are 117 atoms ones more; in the lower diagonally "wrapped" area 118, and in the upper 119; in the upper half of Table 120 atoms. The repeated four AAs at the bottom of the Table make to achieve a diagonal balance with a difference of only one atom; moreover, to establish a sequence from the series of natural numbers: 117, 118, 119, 120. (About generating the Table see in the text.)" (MMR, 2017d, Tab. 4, p. 13). 